JMI Vol. 43 No. 2, Desember 2021

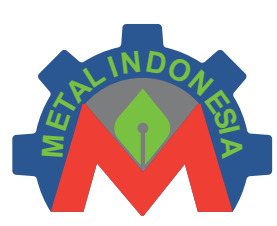

METAL INDONESIA

Journal Homepage:

http://www.jurnalmetal.or.id/index.php/jmi

p-issn: 0126-3463

e-issn: 2548-673X

\title{
SINTESIS ZNO DARI LIMBAH INDUSTRI LOGAM DENGAN METODE HIDROTERMAL MENGGUNAKAN AGEN PENGENDAPAN ASAM OKSALAT $\left(\mathrm{C}_{2} \mathrm{H}_{2} \mathrm{O}_{4}\right)$
}

\section{ZNO SYNTHESIS FROM METAL INDUSTRY WASTE WITH HYDROTERMAL METHOD USING OXALIC ACID $\left(\mathrm{C}_{2} \mathrm{H}_{2} \mathrm{O}_{4}\right)$ PRECIPITATION AGENT}

\author{
Erane Dio Putra ${ }^{1}$, Rifqi Ikhwanuddin ${ }^{1}$, Lukman Nulhakim ${ }^{1}$, Widi Astuti ${ }^{2}$ \\ ${ }^{1}$ Program Studi Teknik Fisika, Institut Teknologi Sumatera (ITERA), Jl. Terusan Ryacudu, Way \\ Huwi, Jati Agung, Lampung Selatan, Lampung \\ ${ }^{2}$ Balai Penelitian Teknologi Mineral, Badan Riset dan Inovasi Nasional (BRIN), Jl. Ir. Sutami Km. 15, \\ Tanjung Bintang, Lampung Selatan, Lampung \\ Email: widi.mineral@gmail.com
}

\begin{abstract}
Abstrak
Limbah industri logam penghasil baja tahan karat yang berasal dari tungku busur listrik masih mengandung zinc $(\mathrm{Zn})$ sebanyak 50-60\% ingin diolah kembali untuk membentuk zink oksida $(\mathrm{ZnO})$ dengan perlakuan metode hidrotermal. Tujuan dari penelitian ini adalah mempelajari pengaruh proses pelindian dan pengendapan terhadap ektraksi Zn dari prekursor limbah logam dan mengetahui apakah dapat terbentuk produk $\mathrm{ZnO}$. Terdapat dua proses persiapan utama yang dilakukan pada penelitian ini berupa proses pelindian menggunakan asam asetat $(\mathrm{CH} 3 \mathrm{COOH}) 1 \mathrm{M}$ dan proses pengendapan menggunakan Asam Oksalat (C2H2O4) 1M. Proses hidrotermal dilakukan dengan tiga variabel suhu $\left(120,150,200^{\circ} \mathrm{C}\right)$ dan tiga variabel waktu $(1,3,6$ jam). Terdapat tiga macam karakterisasi yang dilakukan yaitu menggunakan $U V$-Vis spectroscopy, $X$-ray diffration (XRD), dan $X$-ray fluorescence (XRF). Pada UV-Vis menunjukkan terdapat kenaikan absorbansi pada sampel di panjang gelombang $365 \mathrm{~nm}$, hasil karakterisasi XRF menunjukkan kandungan $\mathrm{Zn}$ meningkat dari 50-60\% menjadi 9495\%, karakterisasi XRD menunjukkan bahwa sampel yang dibuat masih berupa zinc oksalat $\left(\mathrm{Zn}\left(\mathrm{C}_{2} \mathrm{O}_{4}\right)\right)$ dan belum terbentuk senyawa $\mathrm{ZnO}$.
\end{abstract}

Kata Kunci : limbah logam, pengendapan, asam oksalat, pelindian, hidrotermal

Abstract
Stainless steel-producing metal industry waste from electric arc furnaces that still containing 50-60\% of zinc ( $\mathrm{Zn})$ has been recycled to form zinc oxide $(\mathrm{ZnO})$ and treated using the hydrothermal method. The purpose of this study was to learn the effect of leaching and precipitation processes on the extraction of Zn from metal waste precursors and to determine whether $\mathrm{ZnO}$ products can be formed. There are two main preparation processes carried out in this study, such as the leaching process using $1 \mathrm{M}$ acetic acid $(\mathrm{CH} 3 \mathrm{COOH})$ and the precipitation process using $1 \mathrm{M}$ oxalic acid (C2H2O4). The hydrothermal process was carried out with three temperature variables $(120,150$, $200^{\circ} \mathrm{C}$ ) and three time variables $(1,3,6 \mathrm{~h})$. Samples was characterized by UV-Vis spectroscopy, X-ray diffration $(X R D)$, and $X$-ray fluorescence $(X R F)$. $U V$-Vis spectrocopy results show there is a rise of absorbance at a wavelength of $365 \mathrm{~nm}, X R F$ characterization results show that the Zn purity of metal waste increases from 50-60\% up to 94-95\%, XRD characterization shows that the samples is still in the form of Zinc Oxalate $(\mathrm{Zn}(\mathrm{C} 2 \mathrm{O} 4))$ and $\mathrm{ZnO}$ compounds have not yet been formed.

Keywords: metal waste, precipitation, oxalic acid, leaching, hydrothermal 


\section{PENDAHULUAN}

Limbah industri adalah sisa pembuangan dari proses di dalam industri yang keberadaannya tidak memiliki nilai ekonomi atau belum memiliki nilai ekonomi dan pada suatu keadaan tertentu memiliki nilai ekonomi negatif seperti mencemari lingkungan. Limbah industri dapat berupa limbah padat, limbah cair, maupun limbah gas (Widjajanti, 2009). Limbah yang dihasilkan pada industri logam biasanya limbah padat yang masih mengandung unsur-unsur seperti nikel $(\mathrm{Ni})$, tembaga $(\mathrm{Cu})$, kromium $(\mathrm{Cr})$, merkuri $(\mathrm{Hg})$, timbal $(\mathrm{Pb})$, cadmium $(\mathrm{Cd})$, dan zinc $(\mathrm{Zn})$. Limbah logam pada penelitian ini merupakan limbah pada yang dihasilkan oleh industri penghasil baja tahan karat dari tungku busur listrik. Limbah ini mengandung beberapa logam seperti zinc (Zn). Kandungan Zn dalam limbah ini mencapai $50-60 \%$, sehingga sangat berpotensi untuk diolah kembali untuk dapat menghasilkan senyawa $\mathrm{Zn}$ seperti zinc oksida $(\mathrm{ZnO})$ (Astuti, et al. 2020). Pada penelitian ini, rute pengolahan yang digunakan adalah rute sintesis $\mathrm{ZnO}$ dengan harapan terbentuk nanopartikel $\mathrm{ZnO}$. zinc oksida memiliki Direct Wide Band Gap $(3,37 \mathrm{eV})$ dan energi ikat eksiton sebesar $60 \mathrm{meV}$ pada suhu kamar (Yang and Park 2019, 1177). ZnO Digunakan dalam banyak aplikasi seperti perangkat gelombang akustik permukaan (surface acoustic wave devices), perangkat sensor gas, laser dan perangkat optoelektronik (Vafaee and Ghamsari 2007, 3265-3268). ZnO biasanya berupa suatu senyawa kimia organik oksida logam yang pada umumnya berbentuk powder (serbuk) (Ramahdita 2011, 105). ZnO digambarkan sebagai bahan anorganik yang merupakan semkionduktor II-VI.

Berbagai metode dapat digunakan untuk membentuk senyawa $\mathrm{ZnO}$, salah satunya adalah metode hidrotermal. Metode hidrotermal memiliki beberapa keuntungan dibandingkan dengan metode konvensional lainnya seperti proses yang sederhana, hemat energi, kontrol nukleasi yang baik, bebas polusi, dispersi yang tinggi, tingkat reaksi tinggi, bentuk yg lebih mudah untuk dikontrol, dan temperature operasi yang rendah jika menggunakan pelarut yang tepat (Ramahdita 2011, 105). Jarak atau range temperatur yang tepat untuk mensintesis nanopartikel $\mathrm{ZnO}$ adalah sekitar $100^{\circ} \mathrm{C}$ sampai $200^{\circ} \mathrm{C}$ saja, apabila variabel temperatur dan waktu berlebih, maka nanopartikel yang dihasilkan akan makin tidak baik (Katiyar, et al. 2020, 1-7).
Pada penelitian ini juga dilakukan metode hidrometalurgi sederhana sebelum dilakukannya hidrotermal (preparation) yaitu pelindian dan pengendapan menggunakan asam oksalat. Pada pelindian digunakan reagen asam asetat dikarenakan pada penelitian sebelumnya, pelindian limbah logam tersebut dengan asam asetat menghasilkan persentase $\mathrm{Zn}$ tertinggi dibanding reagen lainnya (Astuti, et al. 2020).

Tujuan penlitian ini adalah melaksanakan rute pengolahan limbah logam dengan metode Hidrotermal dan agen pengendapan Asam Oksalat $\left(\mathrm{C}_{2} \mathrm{H}_{2} \mathrm{O}_{4}\right)$, dan untuk mengetahui pengaruh rute pada pengolahan limbah logam melalui hasil Karakterisasi U-Vis spectroscopy, XRF, dan XRD.

\section{MATERIAL DAN METODE \\ Bahan dan Alat Penelitian}

Peralatan proses sintesis yang digunakan adalah gelas baker, labu ukur, gelas ukur, erlenmeyer, kertas saring Whatman no.32, pengaduk, pengaduk magnetik, spinbar, pipet tetes, oven, furnace, mortar alu, dan autoclave $50 \mathrm{~mL}$. Karakterisasi sampel menggunakan peralatan $U V$-Vis spetrophotometer (PerkinElmer Lambda 365), X-ray fluorescence (XRF, Epsilon 3 XLE, PANalytical, Belanda), dan X-ray diffraction (XRD, X'pert 3 Powder, PANalytical, Belanda).

\section{Metode Penelitian}

Pengolahan limbah logam yang mengandung $\mathrm{Zn}$ dilakukan menggunakan tiga tahap utama yaitu proses pelindian, pengendapan dengan asam oksalat, dan hidrotermal (Gambar 1). Proses pelindian dilakukan dengan asam asetat $\left(\mathrm{CH}_{3} \mathrm{COOH}\right) 1 \mathrm{M}$ dengan suhu pelindian $80^{\circ} \mathrm{C}$ selama 5 jam lalu disaring dengan kertas Whatman No.42. Selanjutnya pengendapan menggunakan asam oksalat $\left(\mathrm{C}_{2} \mathrm{H}_{2} \mathrm{O}_{4}\right) 1 \mathrm{M}$ dengan perbandingan hasil pelindian dan asam oksalat 1:1. Setelah proses pengendapan juga dilakukan hidrotermal dengan suhu $\left(120,150,200^{\circ} \mathrm{C}\right)$ dan waktu (1, 3, 6 jam).

Hasil hidrotermal yang masih dalam bentuk aqueous diencerkan sebanyak 100 kali lalu dikarakterisasi menggunakan UV-Vis spetrophotometer. Kemudian hasil hidrotermal yang masih dalam bentuk aqueous disaring menggunakan kertas Whatman No. 42 untuk dikarakterisasi menggunakan XRF dan XRD. 


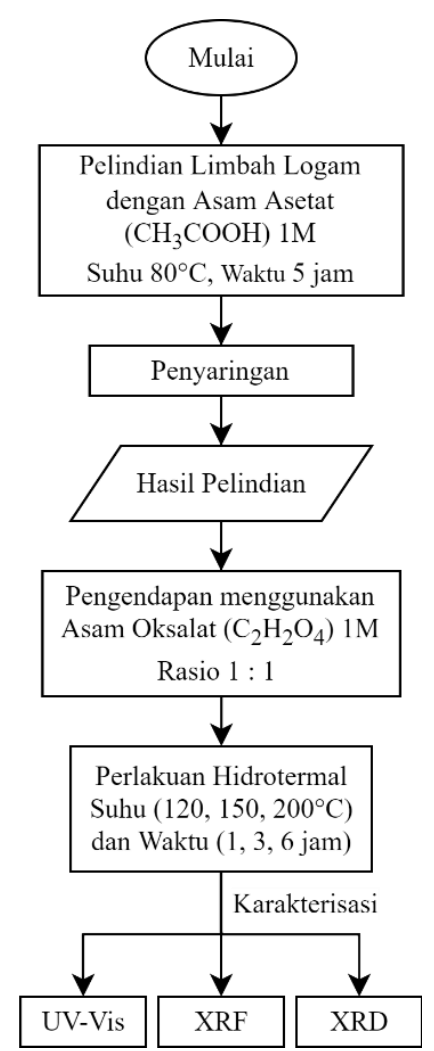

Gambar 1. Diagram Alir Metode Penelitian

\section{HASIL DAN PEMBAHASAN}

\section{Karakterisasi Limbah Logam}

Bahan material yang digunakan pada penelitian kali ini adalah limbah industri logam pembuatan besi baja tahan karat (stainless steel) dari alat bernama electric arc funace dengan ukuran partikel $<100$ mesh yang didalamnya terdapat kandungan zinc $(\mathrm{Zn})$ mencapai 50-60\%.

Dari data XRD Gambar 2 dapat ditentukan bahwa $\mathrm{Zn}$ yang terkandung dalam limbah logam dalam bentuk zincite $(\mathrm{ZnO})$, simonkolleite $\left(\mathrm{H}_{10} \mathrm{C}_{12} \mathrm{O}_{9} \mathrm{Zn}_{5}\right)$, dan magnetite $\left(\mathrm{Fe}_{3} \mathrm{O}_{4}\right)$ (Astuti, et al. 2020). Proses leaching menggunakan
AsamAsetat 1M yang dibuat dari Asam Asetat Glasial 17,5M, pada proses pengendapan menggunakan Asam Oksalat. Aquades juga berperan pada setiap proses pengenceran pada penelitian ini.

\section{Proses Pelindian Limbah Logam}

Proses leaching dilakukan tiap $500 \mathrm{~mL}$ asam asetat dengan prekursor limbah industri sebanyak 25 gram. Kedua materi tersebut dicampur dan dipanaskan diatas hot plate dengan suhu $80^{\circ} \mathrm{C}$ dan kecepatan pengadukan $500 \mathrm{rpm}$ selama 5 jam. Berikut persamaan reaksinya:

$\mathrm{Zn}(\mathrm{s})+2 \mathrm{CH}_{3} \mathrm{COOH}(\mathrm{aq}) \rightarrow \mathrm{Zn}\left(\mathrm{CH}_{3} \mathrm{COO}\right)_{2}(\mathrm{aq})+\mathrm{H}_{2}(\mathrm{~g})$

Zinc + Asam Asetat $\rightarrow$ Zinc Asetat + Hidrogen

Pada reaksi diatas, limbah yang mengandung $\mathrm{Zn}$ bereaksi dengan asam asetat dalam proses pelindian untuk menghasilkan zinc asetat dan gas hidrogen dalam bentuk gas, kemudian hasil pelindian disaring untuk memisahkan larutan dengan residue untuk menghasilkan larutan zinc asetat.

\section{Proses Pengendapan dan Hidrotermal}

Pada proses pengendapan, asam oksalat yang dibutuhkan adalah $1: 1$ terhadap jumlah hasil pelindian. Proses pengendapan dilakukan dengan mencampurkan kedua larutan tersebut lalu dilakukan pengadukan dengan hot plate dalam suhu ruang $\left(27^{\circ} \mathrm{C}-30^{\circ} \mathrm{C}\right)$ sampai terlihat endapan. Berikut persamaan reaksinya:

$$
\begin{gathered}
\mathrm{Zn}\left(\mathrm{CH}_{3} \mathrm{COO}\right)_{2}(\mathrm{aq})+\mathrm{C}_{2} \mathrm{H}_{2} \mathrm{O}_{4}(\mathrm{aq}) \rightarrow \\
2 \mathrm{CH}_{3} \mathrm{COOH}(\mathrm{aq})
\end{gathered} \underset{\mathrm{Zn}\left(\mathrm{C}_{2} \mathrm{O}_{4}\right)(\mathrm{aq})+}{\ldots . .(3}
$$

Zinc Asetat + Asam Oksalat $\rightarrow$ Zinc Oksalat + Asam Asetat

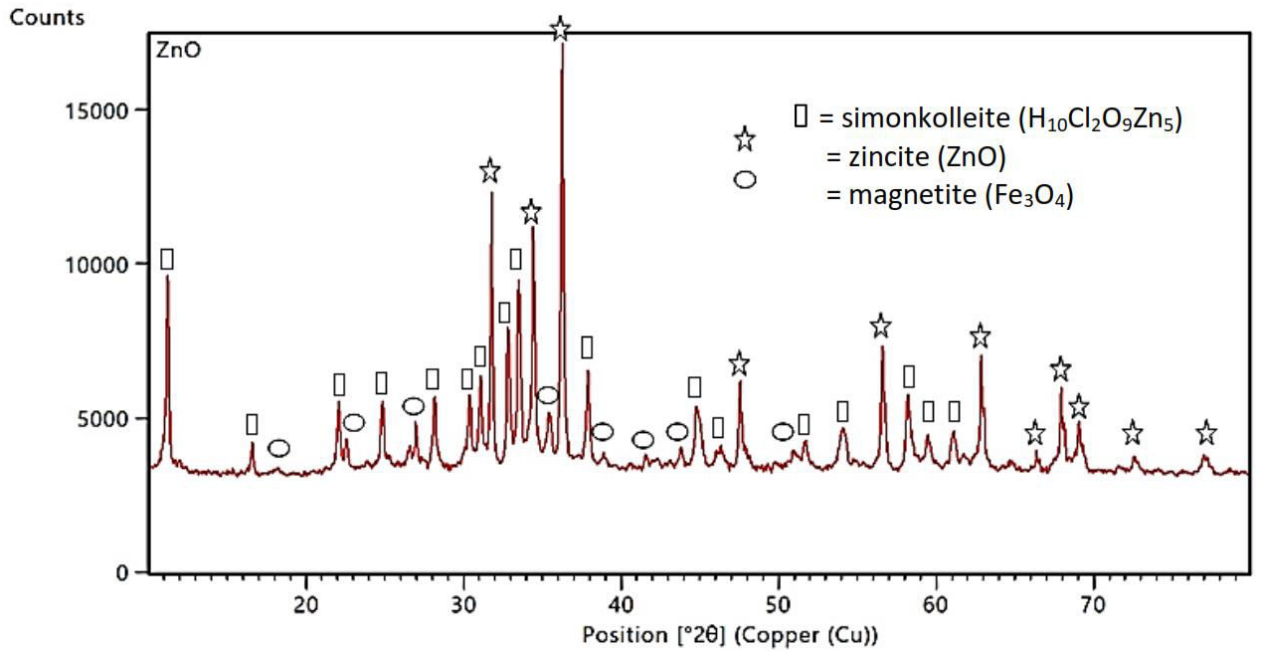

Gambar 2. Pola XRD Limbah Logam 
Hasil pelindian berupa zinc asetat bereaksi dengan asam oksalat untuk menghasilkan zinc oksalat dalam bentuk endapan dan asam asetat (Rahman, et al. 2013, 170-174). Perlakuan hidrotermal dilakukan pada larutan hasil proses pengendapan tersebut. Berikut persamaan reaksinya:

$$
\mathrm{Zn}\left(\mathrm{C}_{2} \mathrm{O}_{4}\right)(\mathrm{aq}) \rightarrow \mathrm{ZnO}(\mathrm{s})+\mathrm{CO}_{2}+\mathrm{CO} \ldots \text { (3.3) }
$$

\section{Zinc Oksalat $\rightarrow$ Zinc Oksida + Karbon Dioksida +} Karbon Monoksida

Pada reaksi diatas, larutan yang mengandung endapan $\mathrm{ZnO}$ diperlakukan hidrotermal hingga suhu $200^{\circ} \mathrm{C}$ untuk memecah seng oksalat menjadi zinc oksida dan karbon dioksida serta karbon monoksida dalam bentuk gas (Maryani, et al. 2012, 29-35).

\section{Karakterisasi UV-Vis Hasil Hidrotermal}

Pada Gambar 3 karakterisasi UV-Vis, menunjukkan puncak absorbansi terletak pada $365 \mathrm{~nm}$ dengan nilai absorbansi tertinggi yaitu 0,6 pada variabel $3 \mathrm{jam}, 200^{\circ} \mathrm{C}$. Proses hidrotermal dapat meningkatkan absorbansi, namun belum ada perubahan panjang gelombang pada peak jika dibandingkan dengan variabel sebelum dilakukannya hidrotermal (garis hijau).

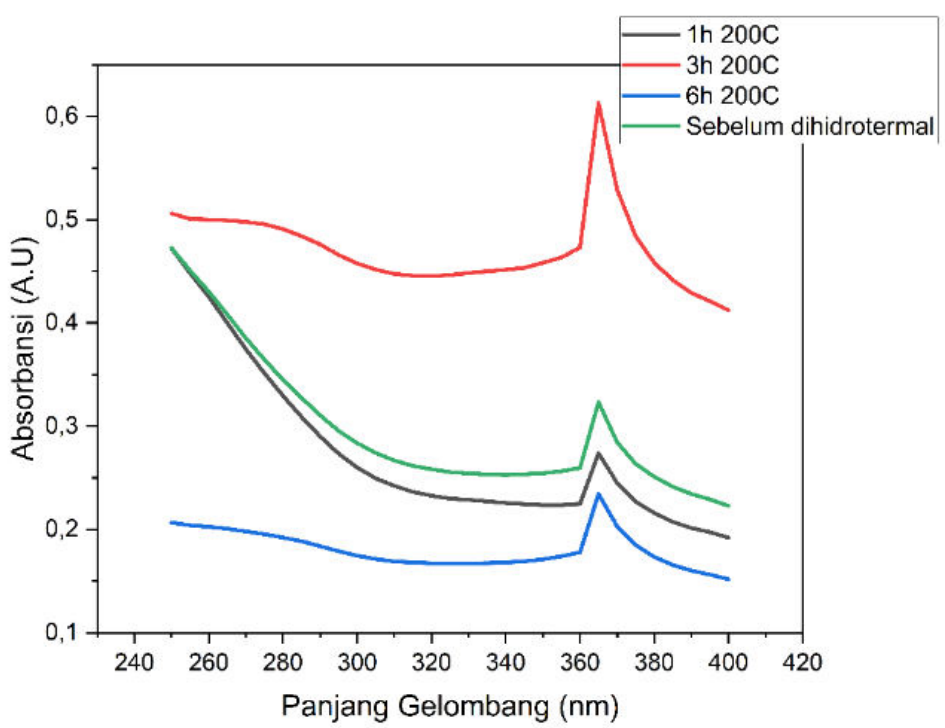

Gambar 3. Hasil Karakterisasi UV-Vis Hidrotermal pada Variabel $200^{\circ} \mathrm{C}$

Berdasarkan persamaan energi foton (photon energy) yaitu $\mathrm{E}(\mathrm{eV})=1240 . \mathrm{eV} . \mathrm{nm} / \lambda$ (panjang gelombang $\lambda$ dalam satuan $\mathrm{nm}$ ), didapat bahwa besar energi foton yang didapat dari hasil penelitian adalah $3,39 \mathrm{eV}$, yang artinya konsisten terhadap nilai energi foton dari $\mathrm{ZnO}$ yaitu $3,37 \mathrm{eV}$ sesuai pada Gambar 2 dengan panjang gelombang $365 \mathrm{~nm}$ (Rahman, et al. 2013, 170174).

\section{Karakterisasi XRF Padatan dari Hasil Hidrotermal}

Tabel 1 menujukkan hasil dari karakterisasi seluruh sampel hidrotermal, dapat dilihat bahwa rata-rata kandungan unsur $\mathrm{Zn}$ yang terkandung dalam masing-masing sampel mencapai $94 \%$. proses ini tidak terjadi dikarenakan perlakuan hidrotermal hanya memiliki batas suhu aman $200^{\circ} \mathrm{C}$. Hal tersebut yang menyebabkan data XRD menunjukkan bahwa sampel masih berbentuk zinc oksalat.

Berdasarkan kandungan $\mathrm{Zn}$ yang terkandung dalam limbah logam tersebut sebelum diproses yaitu sekitar 50-60\% (Astuti, et al. 2020), artinya proses pelindian dan pengendapan dapat meningkatkan tingkat kemurnian $\mathrm{Zn}$ yang terkandung didalam limbah logam tersebut hingga ke angka $94 \%$.

\section{Karakterisasi XRD Padatan dari Hasil Hidrotermal}

Pada Gambar 4 menampilkan hasil karakterisasi XRD pada variabel suhu $200^{\circ} \mathrm{C}$ disertai dengan data standar XRD JCPDS (Joint Committee on Powder Diffraction Standards) untuk ZnO (JCPDS 036-1451) dan zinc oksalat (JCPDS 025-1029), dapat dilihat jika dibandingkan dengan JCPDS zinc oksalat, lima puncak tertinggi yang ada dalam data JCPDS 
zinc oksalat muncul pada data XRD sampel, namun

Tabel 1. Hasil Karakterisasi XRF

\begin{tabular}{|c|c|c|c|c|c|c|}
\hline \multirow{2}{*}{ Variabel } & \multicolumn{7}{|c|}{ Komposisi (\%) } \\
\cline { 2 - 7 } & $\mathrm{Zn}$ & $\mathrm{Mn}$ & $\mathrm{Ca}$ & $\mathrm{Pb}$ & $\mathrm{Ni}$ & $\mathrm{Cu}$ \\
\hline $1 \mathrm{H} 120^{\circ} \mathrm{C}$ & 94,13 & 1,75 & 1,16 & 0,55 & 1,35 & 0,33 \\
\hline $3 \mathrm{H} 120^{\circ} \mathrm{C}$ & 94,63 & 1,71 & 1,07 & 0,57 & 0,36 & 0,34 \\
\hline $6 \mathrm{H} 120^{\circ} \mathrm{C}$ & 94,57 & 1,70 & 1,03 & 0,61 & 0,36 & 0,33 \\
\hline $1 \mathrm{H} 150^{\circ} \mathrm{C}$ & 94,47 & 1,72 & 1,18 & 0,58 & 0,35 & 0,32 \\
\hline $3 \mathrm{H} 150^{\circ} \mathrm{C}$ & 94,60 & 1,66 & 1,04 & 0,56 & 0,36 & 0,33 \\
\hline $6 \mathrm{H} 150^{\circ} \mathrm{C}$ & 94,58 & 1,68 & 0,95 & 0,51 & 0,37 & 0,32 \\
\hline $1 \mathrm{H} \mathrm{200}{ }^{\circ} \mathrm{C}$ & 94,64 & 1,68 & 1,06 & 0,49 & 0,36 & 0,33 \\
\hline $3 \mathrm{H} 200^{\circ} \mathrm{C}$ & 94,31 & 1,66 & 0,90 & 0,46 & 0,36 & 0,33 \\
\hline $6 \mathrm{H} \mathrm{200}{ }^{\circ} \mathrm{C}$ & 95,67 & 1,58 & 0,14 & 0,38 & 0,38 & 0,31 \\
\hline
\end{tabular}

dikarenakan sintesis yang dilakukan berasal dari data JCPDS ZnO, tidak terlihat puncak yang bahan limbah maka masih terdapat beberapa mirip dan memiliki karakteristik yang jauh puncak lainnya yang merupakan pengotor berbeda, bisa disimpulkan bahwa pada proses (impurity). Jika puncak-puncak yang terdapat sintesis kali ini terbukti belum dapat membentuk pada data sampel XRD dibandingkan dengan $\mathrm{ZnO}$ dan masih berbentuk zinc oksalat.

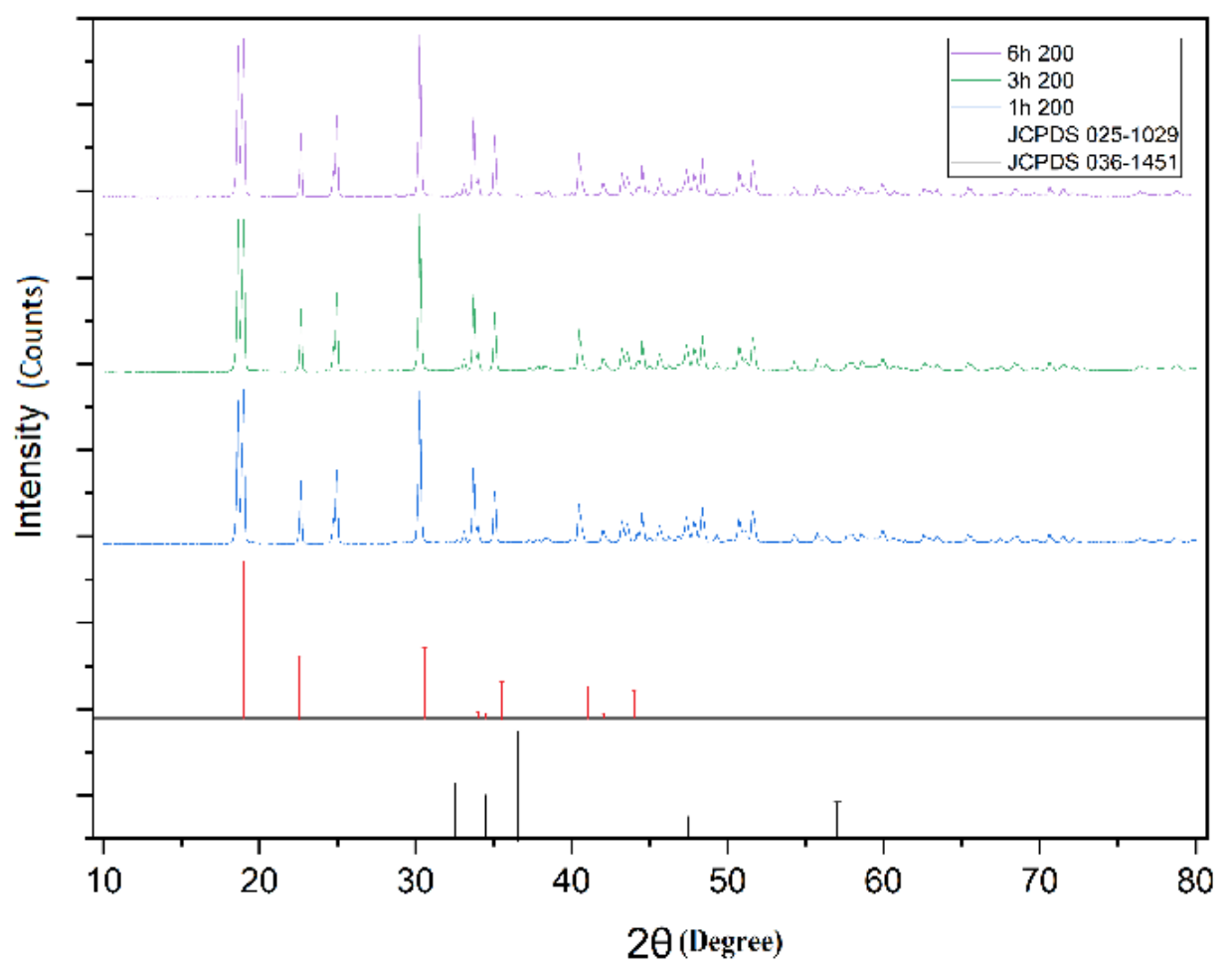

Gambar 4. Hasil Karakterisasi XRD untuk variabel $200^{\circ} \mathrm{C}$ serta ZnO JCPDS 036-1451, dan Zinc Asetat JCPDS 025-1029

Menurut uji data DTA (Differential Thermal Analysis), zinc oksalat akan mengurai apabila dipanaskan (dikalsinasi) pada suhu $600^{\circ} \mathrm{C}$. Prinsip pengukuran DTA ini adalah analisis perbedaan suhu yang terjadi antara material sampel yaitu zinc oksalat dengan pembanding alumina $\left(\mathrm{Al}_{2} \mathrm{O}_{3}\right)$. 


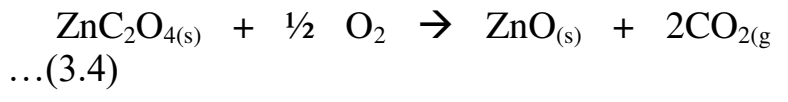

\section{Zinc Oksalat $\rightarrow$ Zinc Oksida + Karbon Dioksida}

Pada reaksi diatas, zinc oksalat dialiri gas $\mathrm{O}_{2}$ (dikalsinasi) untuk menghasilkan zinc oksida dan gas karbon dioksida yang akan keluar dalam bentuk gas (Elizabeth, 2018). Pada penelitian ini, proses ini tidak terjadi dikarenakan perlakuan hidrotermal hanya memiliki batas suhu aman $200^{\circ} \mathrm{C}$. Hal tersebut yang menyebabkan data XRD menunjukkan bahwa sampel masih berbentuk zinc oksalat.

\section{KESIMPULAN}

Setelah dilakukan penelitian ini, dapat diambil kesimpulan sebagai berikut:

a. Hasil karakterisasi UV-Vis menunjukkan hasil proses Hidrotermal belum dapat mengubah karakteristik dari panjang gelombang sampel. Namun, beberapa variabel meningkatkan absorbansinya.

b. Hasil karakterisasi XRF menujukkan proses pelindian pada pengolahan limbah logam dapat meningkatkan kadar kandungan $\mathrm{Zn}$ yang terdapat dalam limbah logam hingga $94 \%$.

c. Hasil karakterisasi XRD menunjukkan proses pelindian serta perlakuan hidrotermal membentuk zinc oksalat dan belum dapat menghasilkan zinc oksida, dikarenakan zinc oksalat hanya dapat mengurai pada suhu $600^{\circ} \mathrm{C}$, yang dimana melewati batas suhu maksimum dari autoclave pada proses hidrotemal.

\section{UCAPAN TERIMAKASIH}

Penulis berterimakasih kepada Balai Penelitian Teknologi Mineral - Badan Riset dan Inovasi Nasional (BRIN) atas penyediaan fasilitas dan pembiayaan dalam penelitian ini.

\section{DAFTAR PUSTAKA}

Astuti, Widi, Agus Haerudin, Istihanah Nurul Eskani, Aulia Pertiwi Tri Yuda, Fajar Nurjaman, Joni Setiawan, Dwi Wiji Lestari, and Himawan Tri Bayu Murti Petrus. "Pengaruh Reagen Pelindian pada Sintesis $\mathrm{ZnO}$ dari Debu Tungku Busur Listrik." Jurnal Rekayasa Proses 14, no. 1 (2020).

Byrappa, K., and M. Yoshimura. "Hydrothermal technology for nanotechnology-a technology for processing of advanced materials." Handbook of Hydrothermal Technology (2013): 615-762.

Darvishi, Elahe, Danial Kahrizi, and Elham Arkan. "Comparison of different properties of zinc oxide nanoparticles synthesized by the green (using Juglans regia L. leaf extract) and chemical methods." Journal of Molecular Liquids 286 (2019): 110831.

Elizabeth, Ivana Cesarima Rambu. "Studi Pelindian Seng Dross dengan Asam Oksalat." (2018).

Fakhari, Shabnam, Mina Jamzad, and Hassan Kabiri Fard. "Green synthesis of zinc oxide nanoparticles: a comparison." Green chemistry letters and reviews 12 , no. 1 (2019): 19-24.

Jalal, Razieh, Elaheh K. Goharshadi, Maryam Abareshi, Majid Moosavi, Abbas Yousefi, and Paul Nancarrow. "ZnO nanofluids: green synthesis, characterization, and antibacterial activity." Materials Chemistry and Physics 121, no. 1-2 (2010): 198-201.

Katiyar, Anu, Nishant Kumar, R. K. Shukla, and Anchal Srivastava. "Substrate free ultrasonic-assisted hydrothermal growth of $\mathrm{ZnO}$ nanoflowers at low temperature." SN applied sciences 2, no. 8 (2020): 1-7.

Maryani, Devi, Gunawan Gunawan, and Khabibi Khabibi. "Penentuan Efisiensi DSSC (DyeSensitized Solar Cell) yang Dibuat dari Semikonduktor $\mathrm{ZnO}$ yang diemban $\mathrm{Fe} 3+$ Melalui Metode Presipitasi." Jurnal Kimia Sains dan Aplikasi 15, no. 1 (2012): 29-35.

Neldawati, Neldawati. "Analisis nilai absorbansi dalam penentuan kadar flavonoid untuk berbagai jenis daun tanaman obat." Pillar of Physics 2, no. 1 (2013).

Peelman, Sebastiaan, Zhi HI Sun, Jilt Sietsma, and Yongxiang Yang. "Leaching of rare earth elements: review of past and present technologies." Rare earths industry (2016): 319-334.

Pillai, Akhilash Mohanan, Vishnu Sankar Sivasankarapillai, Abbas Rahdar, Jithu Joseph, Fardin Sadeghfar, K. Rajesh, and George Z. Kyzas. "Green synthesis and characterization of zinc oxide nanoparticles with antibacterial and antifungal activity." Journal of Molecular Structure 1211 (2020): 128107.

Rahman, Qazi Inamur, Musheer Ahmad, Sunil Kumar Misra, and Minaxi Lohani. "Effective photocatalytic degradation of 
rhodamine $\mathrm{B}$ dye by $\mathrm{ZnO}$ nanoparticles." Materials Letters 91 (2013): 170-174.

Ramahdita, Ghiska. "Karakterisasi Nanopartikel $\mathrm{ZnO}$ Hasil Sintesis Dengan Metode Presipitasi dan Perlakuan PraHidrotermal." Depok, Teknik Metalurgi Dan Material, Universitas Indonesia (2011): 105.

Richardson, J. F., Harker, J. H.;, Backhurst, J. R. (2002), Richardson, J. F., Harker, J. H., Backhurst, J. R. Chemical Engineering (Fifth Edition), Chemical Engineering Series, Butterworth-Heinemann, 502-541.

Salam, Hasna Abdul, Rajeshwari Sivaraj, and R. Venckatesh. "Green synthesis and characterization of zinc oxide nanoparticles from Ocimum basilicum L. var. purpurascens Benth.-Lamiaceae leaf extract." Materials letters 131 (2014): 1618.

Sirelkhatim, Amna, Shahrom Mahmud, Azman Seeni, Noor Haida Mohamad Kaus, Ling Chuo Ann, Siti Khadijah Mohd Bakhori, Habsah Hasan, and Dasmawati Mohamad. "Review on zinc oxide nanoparticles: antibacterial activity and toxicity mechanism." Nano-micro letters 7, no. 3 (2015): 219-242.

Vafaee, M., and M. Sasani Ghamsari. "Preparation and characterization of $\mathrm{ZnO}$ nanoparticles by a novel sol-gel route." Materials Letters 61, no. 14-15 (2007): 3265-3268.

Widjajanti, Endang. "Penanganan limbah laboratorium kimia." Yogyakarta: FMIPA UNY (2009).

Yang, Guijun, and Soo-Jin Park. "Conventional and microwave hydrothermal synthesis and application of functional materials: A review." Materials 12, no. 7 (2019): 1177.

Yoshimura, Masahiro, and K. Byrappa. "Hydrothermal processing of materials: past, present and future." Journal of Materials Science 43, no. 7 (2008): 20852103. 